Diabetologia 9, 120-129 (1973)

(C) by Springer-Verlag 1973

\title{
Development, Differentiation and Derivation of the Endocrine Polypeptide Cells of the Mouse Pancreas
}

\author{
Immunofluorescence, Cytochemical and Ultrastructural Studies* \\ A. G. E. Pearse, J.M. Polak and C.M. Heath \\ Department of Histochemistry, RPMS, Hammersmith Hospital, W12 OHS England
}

Received: August 3, 1972, accepted: December 11, 1972

\begin{abstract}
Summary. Studies on the developing mouse pancreas indicate that neuroectodermal cells from the neural crest, identifiable by their APUD-FIF characteristics, colonize the foregut at around the 10 th day. Carried into the pancreatic anlagen, their primitive pleomorphic granules are progressively replaced by spherical granules which are ultimately (around 16 days) identifiable as of A, B or D type. - Insulin and glueagon are first demonstrable, by immunofluorescence, at the $14^{\text {th }}$ day, at which time zymogen granules are detectable by electron microscopy.
\end{abstract}

- It is postulated that the nouroectodermal cell of the neural crest may be the precursor of some or all of the three known endocrine cells of the pancreatic islets. In the case of the $A$ and $D$ cells present evidence is considered sufficiently strong to make this a tenable hypothesis.

Key words: Pancreatic islets, endocrine (APUD) cells, embryology, neural crest, immunofluorescence, ultrastructure.

\section{Introduction}

Numerous and extensive studies on different aspects of the development of the mammalian endocrine pancreas have been made since the pioneer work of Laguesse (1869) [1]. These studies (e.g. Hard, 1944 [2]; McAlpine, 1951 [3]; Ferreira, 1957 [4]; Frye, 1957 [5]; Munger, 1958 [6]; Esterhuizen, 1959 [7]; Golosow and Grobstein, 1962 [8]; Grillo, 1964 [9]; Hellman, 196566 [10]; Pictet, Clark, Renold, Williams and Rutter, 1968 [11]; Wessells and Rutter, 1969 [12]; Perrier, 1970 [13]; Spooner, Walther and Rutter, 1970 [14]; Pictet, Levine, Phelps and Rutter, 1971 [15]) have produced a mass of controversial findings. There is, however, universal acceptance of the view that, whatever their subsequent behaviour or degree of autonomy, the majority of endocrine cells of the islets are derived from the duct epithelium. As the sole exception it is conceded by some that acinar-insular transitions may also occur.

On the other hand it has been shown in the mouse embryo that cells possessing the main characteristics of the APUD series (Pearse, 1969) [16] which develop, in the various tissues of the adult, into fully functional endocrine polypeptide cells, arise from the neural crest. Cells derived from this structure have been shown to invade the pharyngeal tube and its pouches (to give rise to the calcitonin-secreting $\mathrm{C}$ cells (Le Douarin et al., 1970 [17], Pearse and Polak, 1971a [18]) and the carotid body type 1 cells (Le Douarin et al., 1972 [19]) inter alia. Neural crest cells also have been shown to colonize the foregut and its derivatives including the pancreas (Pearse and Polak, $1971 \mathrm{~b}[20]$ ).

* Supported by Grants from the Wellcome Trust and the Cancer Campaign (CMH).
In the adult state three distinct cell types, which can be distinguished by staining, cytochemical and ultrastructural techniques, have been identified as the source of the three known polypeptide hormones of the pancreas. These are the B cell, first shown conclusively to contain insulin by Lacy and Daries (1959) [21], the A cell shown by Baum, Simons, Unger and Madison (1962) [22] to contain glucagon and the D cell, identified as the source of gastrin by Lomsky, Langr and Vortel (1969) [23].

All these cell types possess the cytochemical and ultrastructural characteristics of APUD cells. There is, however, a gap in continuity between the APUD cells from the neural crest which invade the foregut and are carried into its derivatives, including the developing pancreatic diverticula, and the fully differentiated hormone-secreting cells of the adult islets.

Our present investigations involve the application of immunofluorescence, cytochemical, ultrastructural and electron cytochemical techniques to the earliest stages of pancreatic development. They were carried out primarily in order to provide information on the transitional period between the early embryo and, effectively, the adult state. Our objectives were thus to detect the first appearance of the three hormone-containing cells, and to determine their relationships to each other and to the primitive endocrine cell of the gut wall, already shown to be derived from the neural crest. Not possessing an anti-gastrin serum capable of reacting with murine gastrin, we were obliged to confine our immunoffuorescence studies to the two best established hormones, insulin and glucagon. Ultrastructurally, however, we could follow the three cell types individually. 


\section{Material and Methods}

Seventy-two embryos from 11 pregnant CSI albino mice were studied. Gestation was terminated at periods from the 10 th to the 19 th day and the age of each embryo verified from the external features present using criteria established by Grüneberg (1943) [24]. Where possible the pancreas was dissected out (from 14 days onward) otherwise the pancreatic region was fixed as a whole.

Optical Microscopy. The pancreas (from 39 embryos between 10 and 19 days old) was fixed in methanol-free formaldehyde (MFF), as ciescribed by Polak, Bussolati and Pearse (1971) [25], for histology, cytochemistry and immunofluorescence. In addition to staining with haematoxylin and eosin, the Masson-Fontana method (Pearse, 1972) [26] was used to distinguish enterochromaffin granules. For A cell granules we used the silver method of Grimelius (1968) [27], for B cell granules the aldehydefuchsin technique (Gomori, 1952) [28], and for the D cell granules the Davenport method (Hellerström and Hellman, 1960) [29].

Immunofuorescence. Blocks from the pancreatic region (up to the 14th day) and from the whole pancreas (14th day onwards) were fixed in MFF, dehydrated in gradient alcohols, cleared in xylene and embedded in $56^{\circ}$ paraffin wax. Sections $(5 \mu \mathrm{m})$ were cut and mounted on glycerine-albumin coated slides and allowed to dry at $37^{\circ}$ overnight. They were then dewaxed in light petroleum and indirect immunofluorescence techniques (Coons, Leduc and Connolly, 1955) [30] were carried out.

The first layer was either rabbit anti-porcine glucagon antiserum (Polak, Bloom, Coulling and Pearse, 1971) [31] or guinea-pig anti-porcine insulin antiserum (Wellcome) The second layer was either goat anti-rabbit IgG labelled with fluorescein isothiocyanate (Hyland) or fluoresceinlabelled rabbit anti-guinea pig IgG (Hyland). Controls included, 1 . antiserum absorbed with the pancreatic antigen, followed by the second layer, 2 . normal rabbit or guinea-pig serum followed by fluorescein-labelled antiglobulin and, 3. second layer alone.

Sections were observed with a Laborlux microscope fitted with a quartz-iodine lamp or with a Zeiss (Oberkochen) microscope and HB200 mercury vapour lamp. Photographs were taken on Ilford FP4 film.

Electron Microscopy. Blocks from younger embryos, containing the pancreas, and small pieces of the pancreas from older animals, were fixed in $3 \%$ glutaraldehyde in $0.1 \mathrm{M}$ phosphate buffer ( $\mathrm{pH} 7.2$ ) for at least $3 \mathrm{~h}$. After fixation the tissue was washed out for $2 \mathrm{~h}$ in several changes of $0.1 \mathrm{M}$ phosphate buffer ( $\mathrm{pH} 7.2$ ) containing $0.1 \mathrm{M}$ sucrose. They were then post-fixed in $1 \%$ osmium tetroxide in. Millonig buffer ( $\mathrm{pH}$ 7.0) for one hour. After dehydration in ascending grades of ethyl alcohol, and two changes in propylene oxide, the blocks were left overnight at $45^{\circ}$ in a mixture of Araldite resin, hardener and dibutylphthalate. They were then embedded in Araldite mixture with BMDA acceleration and polymerized at $60^{\circ}$. The blocks from the younger embryos were embedded flat in polythene embedding trays and the others in capsules in the usual manner.

Blocks of whole pancreatic region were trimmed on an LKB Pyramitome until the area of the pancreas was reached, this being found by staining $2 \mu \mathrm{m}$ sections with Toluidine blue in $3 \%$ borax. The blocks were then trimmed to a pyramid containing the pancreatic region and ultrathin sections were cut on an LKB Ultratome III microtome. Sections from blocks of pancreas from older animals were also cut on this instrument. All sections were stained with $15 \%$ uranyl acetate in methanol, followed by lead citrate. They were viewed in an AFI EM 6B microscope.

Electron Cytochemistry. In order to provide positive correlation between the DOPA-uptaking, dopamine- loaded APUD cells of neural crest origin, demonstrated by the APUD-FIF method (Pearse and Polak, 1971 b) [20], and the polymorphic granulated primitive endocrine cells observed in electron micrographs of foregut epithelium and pancreatic rudiment, a Masson-Fontana silver reduction method was applied in the following manner:

The pancreatic region from young embryos or the pancreatic glands from older embryos, removed from mothers who had received intraperitoneal doses of 3,4-dihydroxyphenylalanine (100 mg/kg) $2 \mathrm{~h}$ previously, were fixed for $3 \mathrm{~h}$ in $3 \%$ glutaraldehyde in $0.1 \mathrm{M}$ phosphate buffer at $\mathrm{pH}$ 7.2. Avoiding post-fixation in osmium tetroxide, blocks were then processed and embedded in Araldite as described previously.

Ultrathin sections were cut and placed on nickel grids which were then floated on an ammoniacal silver solution for 1 to $4 \mathrm{~h}$ (optimum time $2 \mathrm{~h}$ ) at $60^{\circ} \mathrm{C}$.

The solution was prepared as follows:

Strong ammonia was added dropwise to a $10 \%$ solution of silver nitrate until the precipitate first formed was redissolved. Fresh silver nitrate solution $(10 \%)$ was then added until an opalescence appeared and persisted. To each volume of this 9 volumes of distilled water were added. Grids were then rinsed in distilled water, fixed for 30 sec in $1 \%$ sodium thiosulphate, rinsed again and airdried before viewing in the AEI EM $6 \mathrm{~B}$ microscope.

Control sections from embryos of the same age whose mothers had not received 3,4-dihydroxyphenylalanine were exposed to the silver solution simultaneously. In addition, parallel sections of test and control blocks were stained in the conventional manner.

\section{Results}

The development of the endocrine pancreas could be divided into three stages, the first from day 9 to day 14, the second from day 14 to day 16 , and the third from day 16 onwards. Our results were mainly confined to the first two stages.

Day 10 to Day 14. Sections of the primitive gut at the level of the presumptive pancreatic diverticula $(9-10$ days) showed amongst the epithelial cells of the wall of the intestine, numerous clear cells (Fig. 1). Electron micrographs at this stage revealed endocrine cells of a single type (Fig. 2), containing pleomorphic, moderately electron dense granules. The cell form was often elongated with an apical process reaching or almost reaching the lumen.

Formation of the dorsal pancreas was observed to commence at about the 11th day by the bulging outwards of a group of cells in the upper wall of the intestine. This bulge gave rise to a plump diverticulum closely apposed to and surrounded by condensed mesenchyme (Fig. 3). At this stage (11 days) all specifie granule stains were negative, as were the immunofluorescence reactions for both insulin and glucagon. As shown in Fig. 3, however, the APUD (Amine Precursor Uptake and Decarboxylation) characteristics of the primitive endocrine cells were readily demonstrable by their formaldehyde-induced fluorescence.

At the electron microscope level the undifferentiated cells of the pancreatic rudiment were observed to be round or oval in shape, with dense cytoplasm. containing numerous free ribosomes (Fig. 4). Some of the 
cells contained secretion granules of endocrine type, moderately electron dense, irregular and predominantly nonspherical in shape, and surrounded by a closely attached membrane. Not infrequently mitoses could be observed in these primitive endocrine polypeptide cells.

Between day 12 and day 14 the pancreatic rudiment was observed to grow continuously. Optical microscopy revealed numerous branching cords of primitive cells with occasional glandular lumina (Fig. 5). Specific granule stains and both immunofluorescence reactions remained negative. Ultrastructural studies showed a

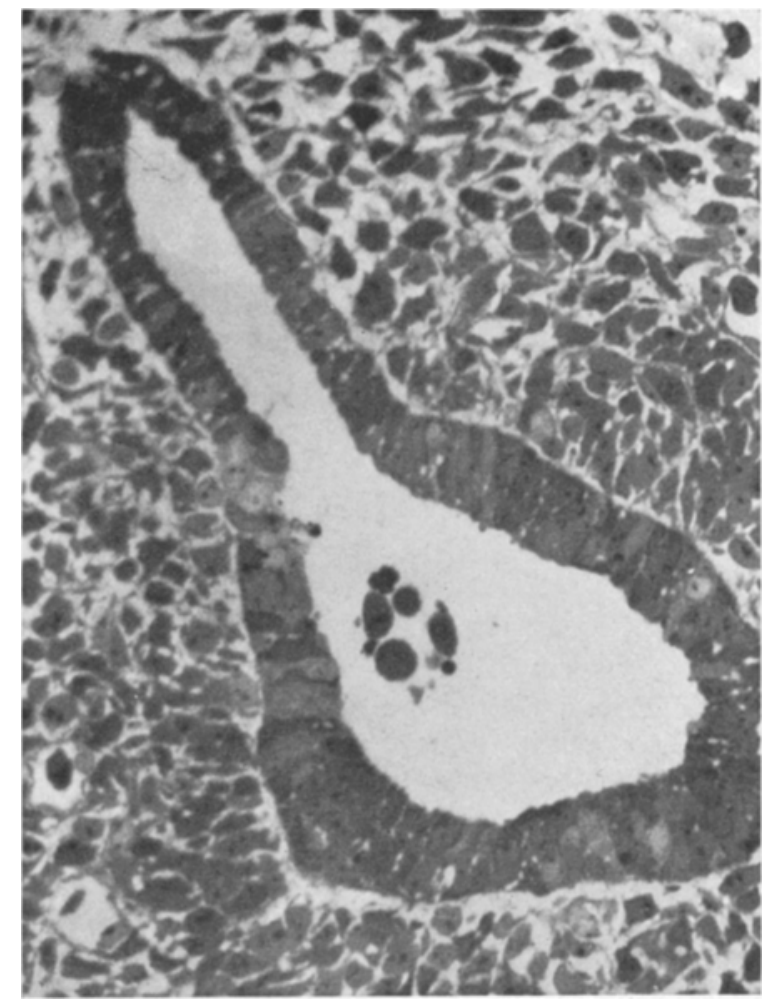

Fig. 1. Mouse Embryo 10.5 days. Resin-embedded $1 \mu \mathrm{m}$ section, stained with Toluidine blue. Shows foregut surrounded by mesenchyme. Many clear cells are visible, some of which extend from the basement membrane to the lumen. $\times 340$

higher proportion of cells containing endocrine-type secretion granules and the latter were more electron dense, with a visible limiting membrane and sometimes a halo in addition (Fig. 6). Intermediate forms could be seen between the primitive undifferentiated endocrine granules and more mature forms, recognizable as $\mathrm{A}$ or B granules. Very often, but not invariably, the granulated endocrine cells were less dense than their undifferentiated companions, some of which presumably were destined to form duct epithelium.

In some of the primitive endocrine cells there were very numerous mitochondria, a prominent Golgi region, much fibrillar material and, sometimes, a cilium. According to Munger (1958) [6] cells with these characteristics were to be regarded as B cells. A further feature of interest was the large number of coated vesicles, clearly shown in Fig. 6. Day 14 to Day 16. The second stage in the development of the endocrine pancreas begins on the 14th day with the onset of islet formation. From day 14 to day 16 insulin-producing and glucagon-producing cells were found either singly or in small clusters (islets). Their granules now had the characteristic appearance found in the adult pancreas and specific staining methods could be carried out successfully. Immunofluorescence for both insulin

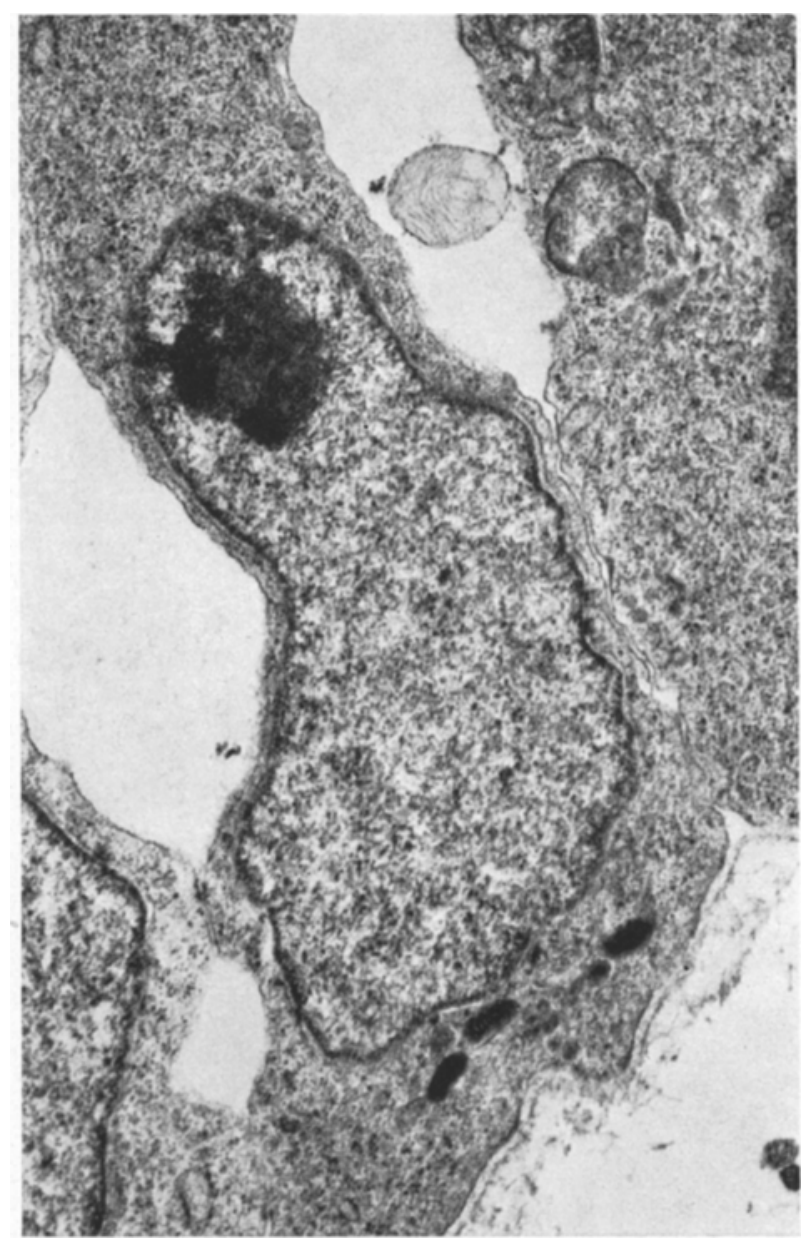

Fig. 2. Mouse Embryo 10.5 days. Shows part of an endocrine (clear)cell in the foregut entoderm, with polymorphic granules adjacent to the basement mombrane.

Lead citrate-Uranyl acetate. $\times 20000$

(Fig. 7) and glucagon (Fig. 8) became positive on the 14th day. Despite repeated efforts we could never show either hormone at an earlier stage than this.

Between the 14th and 15th days zymogen granules became numerous in the epithelial cells of the ducts. Endocrine cells with mixed pleomorphic and adult type granules were still visible. By the 16 th day the pres- 
ence of three types of endocrine cell (A,B,D) could clearly be demonstrated. The predominant endocrine cell, the B cell, situated especially in the centre of the islets, was characterised by the presence of secretory granules (average diameter $500 \mathrm{~nm}$ ), with a highly electron dense eccentric core $(280 \mathrm{~nm})$ and a prominent halo (Figs. 9 and 10). Its eytoplasm was normally darker than that of the other endocrine cells, containing numerous mitochondria, free ribosomes, and a prominent Golgi region. The second type of cell, the A cell, possessed equally electron dense but smaller granules (up to $250 \mathrm{~nm}$, average diameter $190 \mathrm{~nm}$ ) with a con- reducing enterochromaffin cells. Both the pleomorphic endocrine granules in the earliest embryos from DOPAinjected mothers, and the round granules from later stages, were shown to be positive with the MassonFontana method. This indicates that they contain a silver-reducing aldehyde condensation product, derived from the uptake of DOPA and its subsequent decarboxylation and storage as the amine. Hence it follows that they can be correlated absolutely with the cells showing formaldehyde-induced fluorescence after DOPA uptake, which are illustrated in Fig. 3. The evidence of the two methods, taken together, is con-

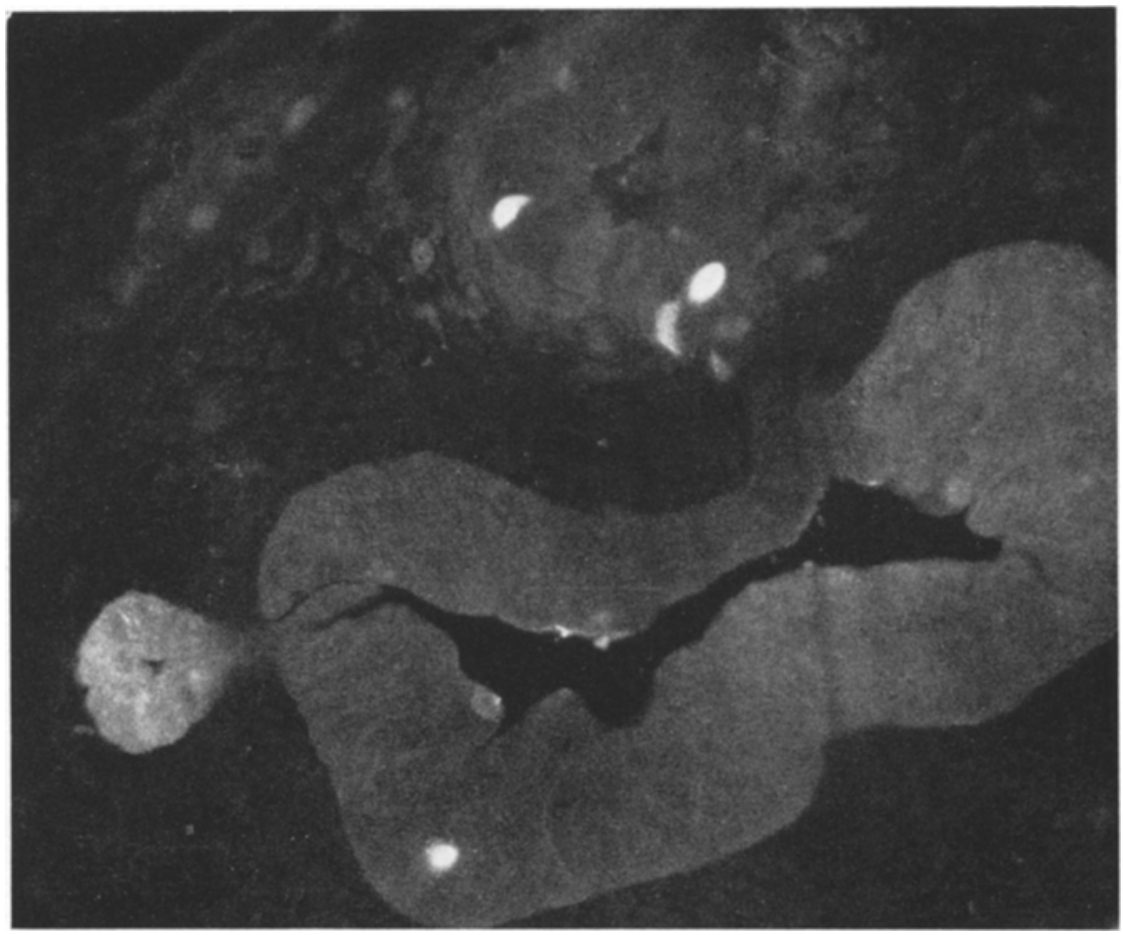

Fig. 3. Mouse Embryo 10-11 days. Processed by the APUD-FIF technique. Shows the presumptive dorsal pancreatic rudiment, surrounded by condensed mesenchyme, in which several fluorescent endocrine (APUD) cells can be seen. $\times 340$

centric core and a slender halo (Fig. 10). This halo was sometimes lacking altogether. The third cell type, the D cell, was characterised by small granules (average diameter $150 \mathrm{~nm}$ ) of variable electron density (Fig. 10), mainly round but often still pleomorphic (Fig. 9).

Specifie staining techniques for A, B and D cells gave much clearer results in the third stage of development, after the 16 th day. At the beginning of the third stage (16-17 days) immunofluorescence reactions showed the $\mathrm{A}$ cells, and the $\mathrm{B}$ cells in their normal adult distribution in the islets.

When the Masson-Fontana method was applied to tissues from embryos from uninjected mothers at no time, in any stage of the development, was a positive result obtained. This indicates, within the limits of the method, that the primitive endocrine cells with pleomorphic granules are not to be regarded as silver- sidered to indicate that the primitive endocrine cells identifiable by electron microscopy are to be regarded. as coming from the neural crest.

\section{Discussion}

We have followed the development and differentiation of the endocrine cells of the pancreas from their earliest stages until the stage of cellular maturity at around 16 days. Our findings can be compared with those of other workers by reference to Table 1 .

With regard to the development of the islets it can be seen that we are in general agreement with the majority opinion while our observations place the origin of the zymogen granules much earlier than previously recorded. From the table it can also be seen 
that there are variable opinions on the A cells. There is one recording of their appearance earlier than noted by us. This paper (Pictet et al., 1971) [15] claims the detection of $\mathrm{A}$ cells containing secretory granules "at the onset of organogenesis".

The earliest observation of B cell granules is another area of wide disagreement but for the $D$ cell no record other than our own has appeared up to the present time.

Broadly speaking we conclude that in relation to the origin of the (dorsal) pancreas at around the 11th. day there is a period of $3-4$ days when the primitive component is responsible for the adoption and maintenance of the more usual spherical form of endocrine granule. It would seem most likely to be connected with the type or amount of membrane and/or matrix lipoprotein synthesized by the cell. An alternative hypothesis would connect it with the nature of the granule contents or with the proportions therein of hormone, hormone precursor, and matrix. If either hypothesis is correct it follows that adult endocrine cells with non-spherical granules must be regarded as less than fully differentiated, perhaps even as potentially transitional.

Table 1. Ontogenesis of Islets, Endocrine and Zymogen Granules

\begin{tabular}{|c|c|c|c|c|c|c|}
\hline \multirow[t]{2}{*}{ Author(s) and Species } & \multirow{2}{*}{$\frac{\text { Islets }}{\text { Noted }}$} & \multicolumn{4}{|c|}{ Granules first observed (Day) } & \multirow{2}{*}{$\begin{array}{l}\text { Techniques } \\
\text { Employed }\end{array}$} \\
\hline & & Zymogen & $\mathrm{A}$ & $\mathrm{B}$ & $\mathrm{D}$ & \\
\hline $\begin{array}{l}\text { Hard }(1944)[2] \\
\text { Rat }\end{array}$ & 13 & - & $\begin{array}{l}\text { After } \\
\text { birth }\end{array}$ & 18 & - & Histology \\
\hline Munger (1958) [6] & 15 & - & After & 13 & - & Histology \\
\hline Mouse & & & birth & $15(\mathrm{EM})$ & & E.M. \\
\hline $\begin{array}{l}\text { Pictet et al. (1968) [11] } \\
\text { Rat }\end{array}$ & - & 16 & - & 13 & - & E.M. \\
\hline $\begin{array}{l}\text { Pictet et al. (1971) [15] } \\
\text { Rat (culture) }\end{array}$ & - & 16.5 & 11.5 & 16.5 & - & E.M. \\
\hline $\begin{array}{l}\text { Ferreira (1957) [4] } \\
\text { Rat }\end{array}$ & - & - & $\begin{array}{l}\text { After } \\
\text { birth }\end{array}$ & 18 & - & E.M. \\
\hline $\begin{array}{l}\text { Hellman }(1965-66)[10] \\
\text { Rat }\end{array}$ & - & - & $\begin{array}{l}\text { After } \\
\text { birth }\end{array}$ & $\begin{array}{l}\text { 2nd half } \\
\text { pregnancy }\end{array}$ & 一 & E.M. \\
\hline $\begin{array}{l}\text { Orci et al.(1969) }[57] \\
\text { Rat }\end{array}$ & - & 一 & 18 & 18 & - & E.M. \\
\hline $\begin{array}{l}\text { Perrier et al. (1969) [58] } \\
\text { Rat }\end{array}$ & 19 & 18 & 17 & 17 & - & E.M. \\
\hline $\begin{array}{l}\text { Spooner et al. }(1970)[14] \\
\text { Rat }\end{array}$ & - & $\begin{array}{l}17 \\
\text { (culture) }\end{array}$ & 17 & 17 & - & E.M. \\
\hline $\begin{array}{l}\text { Frye }(1957)[5] \\
\text { Rat }\end{array}$ & - & - & - & 18 & - & E.M. \\
\hline $\begin{array}{l}\text { Grillo (1964) }[9] \\
\text { Rat and Mouse }\end{array}$ & 13 & - & - & $17-18$ & - & $\begin{array}{l}\text { Cytochemistry } \\
\text { Immunofluorescence }\end{array}$ \\
\hline $\begin{array}{l}\text { Esterhuisen }(1959)[7] \\
\text { Rat }\end{array}$ & - & - & - & 17 & - & E.M. \\
\hline $\begin{array}{l}\text { Wessels and Evans (1968) [59] } \\
\text { Mouse }\end{array}$ & - & Not seen & Not seen & $\begin{array}{l}10 \\
(24 \text { somites })\end{array}$ & - & $\begin{array}{l}\text { E.M. } \\
(18-32 \text { somites })\end{array}$ \\
\hline $\begin{array}{l}\text { Von Denffer and Merts (1972) [60] } \\
\text { Mouse }\end{array}$ & - & - & - & 14 & - & Cytochemistry \\
\hline $\begin{array}{l}\text { This paper } \\
\text { Mouse }\end{array}$ & 14 & $14-15$ & $13-14$ & $13-14$ & $15-16$ & $\begin{array}{l}\text { Histology } \\
\text { Immunofluorescence } \\
\text { E.M. }\end{array}$ \\
\hline
\end{tabular}

endocrine cells, which are dividing very rapidly, mostly contain only pleomorphic granules. Transitions between pleomorphic and round granules are readily observed but it remains difficult to identify the latter confidently as A or B until around the 14th day. Transition from the cell with pleomorphic granules to a fully differentiated endocrine cell is clearest in the case of the $\mathrm{D}$ cell since intermediate forms are still present at 16 days.

Our identification of the pleomorphic granule as the primitive form requires further elucidation. In the adult mammal or bird granules of this type are found in the enterochromaffin cell of the gastrointestinal tract and, in some cases, in the noradrenalin cells of the adrenal medulla. We do not know precisely what
We failed to observe transitional forms between acini and islets. Many workers have found no evidence of this transformation (Bensley, 1911 [32]; Liegner, 1932 [33]; Rathery et al., 1938 [34]; Gomori, 1941 [35]). Others have maintained that the relationship between islets and acini is dynamic rather than static and that conversion of acini into islets and vice versa does occur under functional stimuli, even in the adult (Laguesse, 1905 [36]; Collin et al., 1931 [37]; Florentin el al., 1934 [38], 1936 [39]; Picard, 1935 [40]; Tusques, 1938 [41]; Woerner, 1938 [42]; Aubertin et al., 1938 [43]; Sergeyeva, 1940 [44]; Simard, 1942 [45]). In many of these papers morphological evidence for acinar-insular conversion is lacking while the lack of complete delimitation of the islets by a connective tissue capsule and the 
apparent continuity of the two components is taken by many observers as evidence of transition. Picard (1935) [40] claimed to have observed all stages of the formation of islet cells from acinar cells by a process which he called endocytogenesis. This consisted of the formation of a daughter cell within the acinar cell and of its extrusion as a functioning islet cell.

Evidence derived from electron microscopy provides undoubted examples of cells containing zymogen and endocrine-type granules. Stoeckenius and Kracht (1958) [46] found exocrine and endocrine granules in the same cell in normal rat pancreas and Gusek and rat pancreas regenerating after subtotal removal Marx, Schmidt and Goberna (1970) [52] observed "light cells" migrating from the ducts to form both $A$ and $B$ cells. They concluded that "obviously the new formation of islets takes origin from certain cells of the ductular system". In a further paper Marx, Schmidt, Herrmann and Goberna (1970) [53] reported that they could find no "proof of formation of new functioning beta cells by a transformation of acinar cells". In explanted rat pancreas grown in vitro, on the other hand, Brown et al. (1971) [54] found islet cells in the walls of small ducts and numerous examples of acinar-

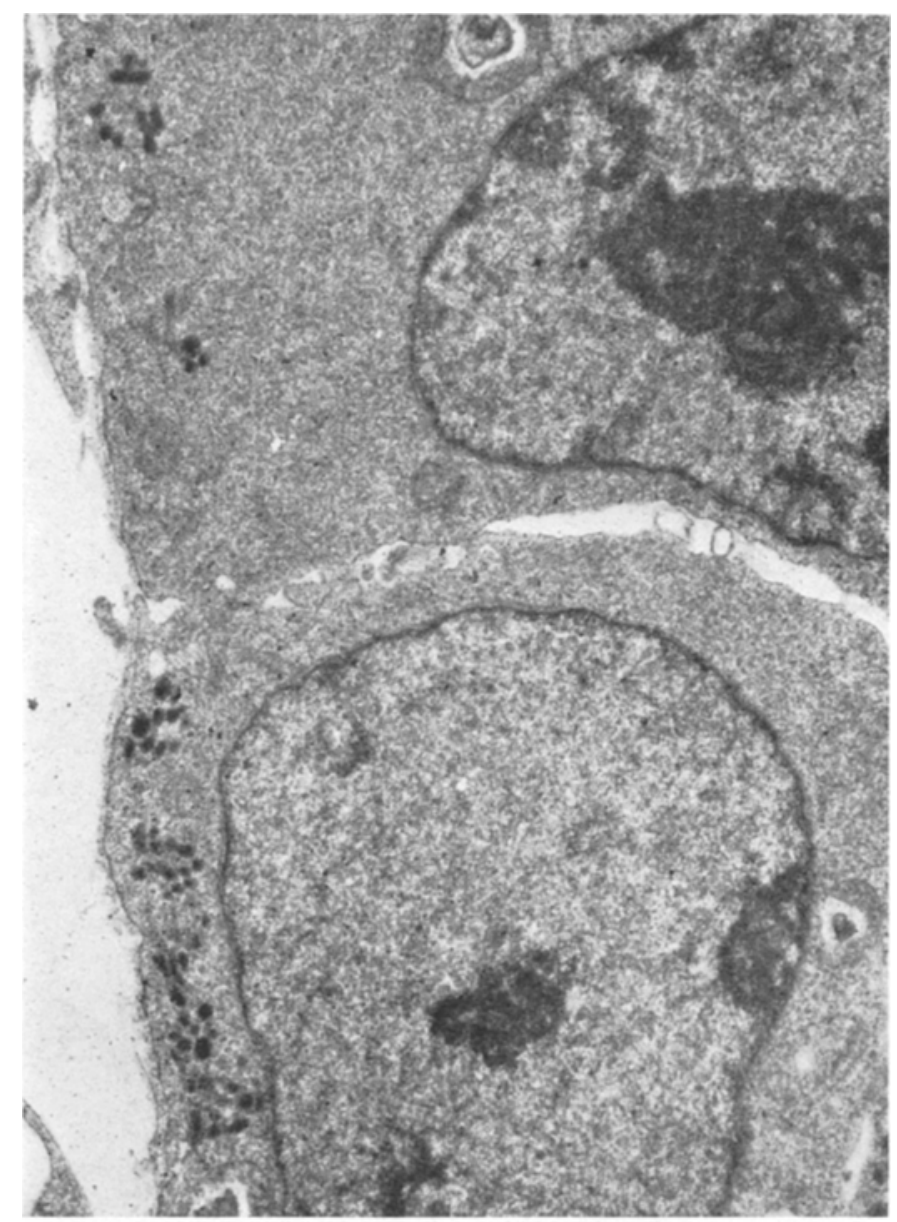

Fig. 4. Mouse Embryo 10-11 days. Section through the pancreatic rudiment. Shows part of two endocrine cells containing mainly pleomorphic granules situated basally in the cell. Lead citrate-Uranyl acetate. $\times 12000$

Kracht (1959) [47] confirmed the existence of acinoinsular transformations in cortisone-treated animals. In the frog, Rana ridibunda, mixed granule cells were recorded by Lange (1968) [48] following their earlier description in the toad by Kobayashi (1966) [49] and Prieto-Diaz et al., (1967) [50]. In the developing pancreas of the chick Dieterlen-Lièvre (1965) [51] observed, in 21 day-old embryos, cells containing mixed granules of different types (zymogen $+\mathrm{A}$; zymogen $+\mathrm{B}$; zymogen $+\mathrm{A}+\mathrm{B}$; and $\mathrm{A}+\mathrm{B}$ ). In the islet transformation. Furthermore, Leduc and Jones (1968) [55] found electron microscopic evidence for acinar-islet cell transformation in the mouse pancreas, and Melmed, Benitez and Holt (1972) [56] described these transformations in the pancreas of a wide variety of animals.

If we consider the contrary view, that the endocrine cells of the pancreas are derived from the migrating APUD cells of the neural crest, a number of alternatives exist. $A$ priori there are three possibilities for 


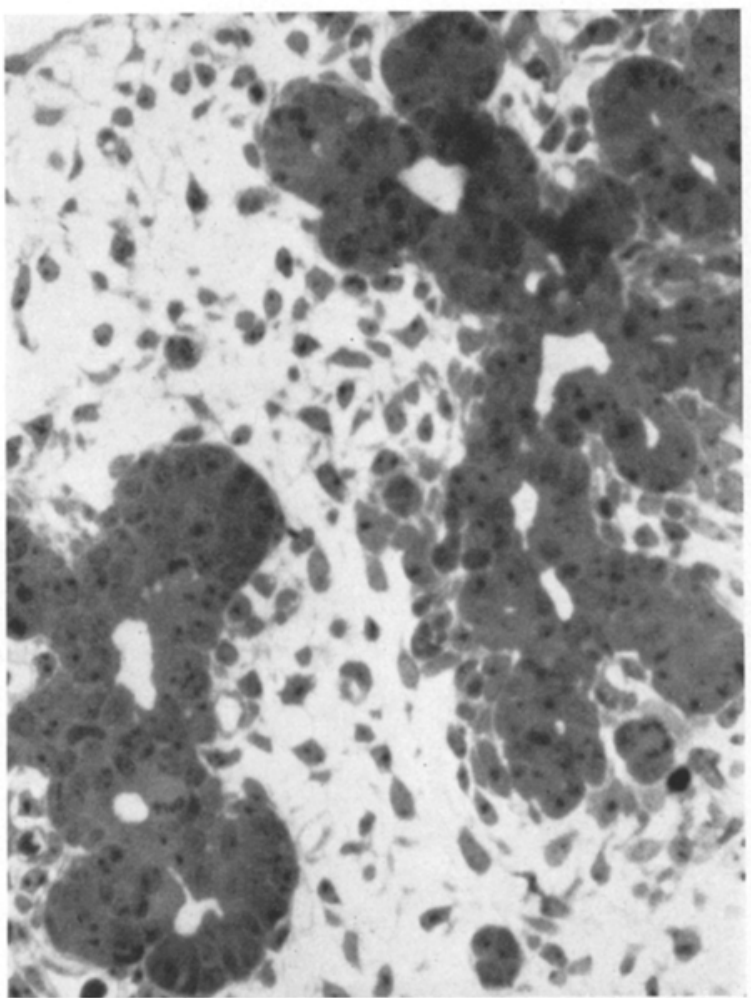

Fig. 5. Mouse Embryo 13 days. Resin- embedded $1 \mu \mathrm{m}$ section, stained with Toluidine blue. The developing pancreas consists of duct-like epithelial cords with numerous lumina. Mitoses are frequent. $\times 340$

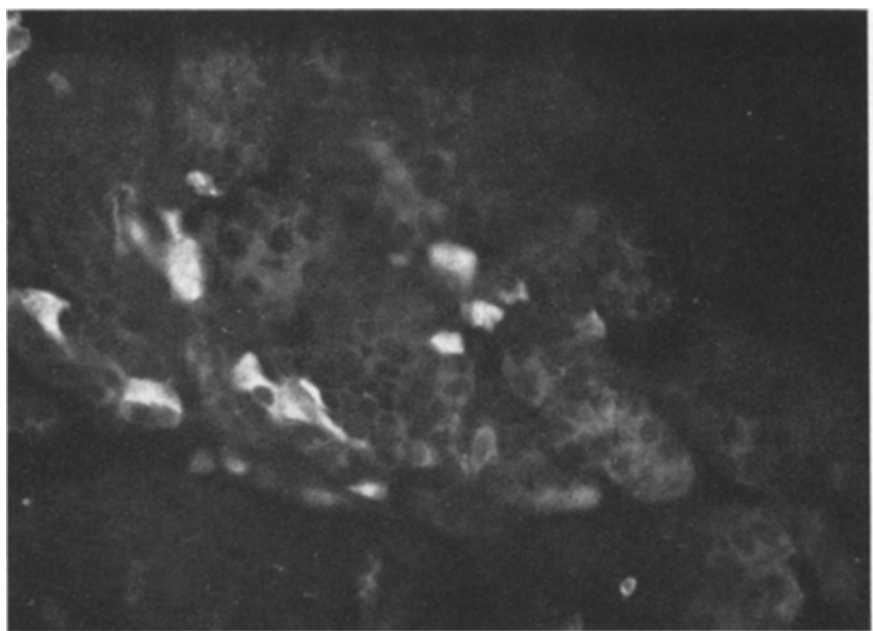

Fig. 7. Mouse Embryo 14 days. Indirect technique for immunofluorescence. Anti-human and porcine insulin sera react with $B$ cells in the now recognizable islets. $\times 300$

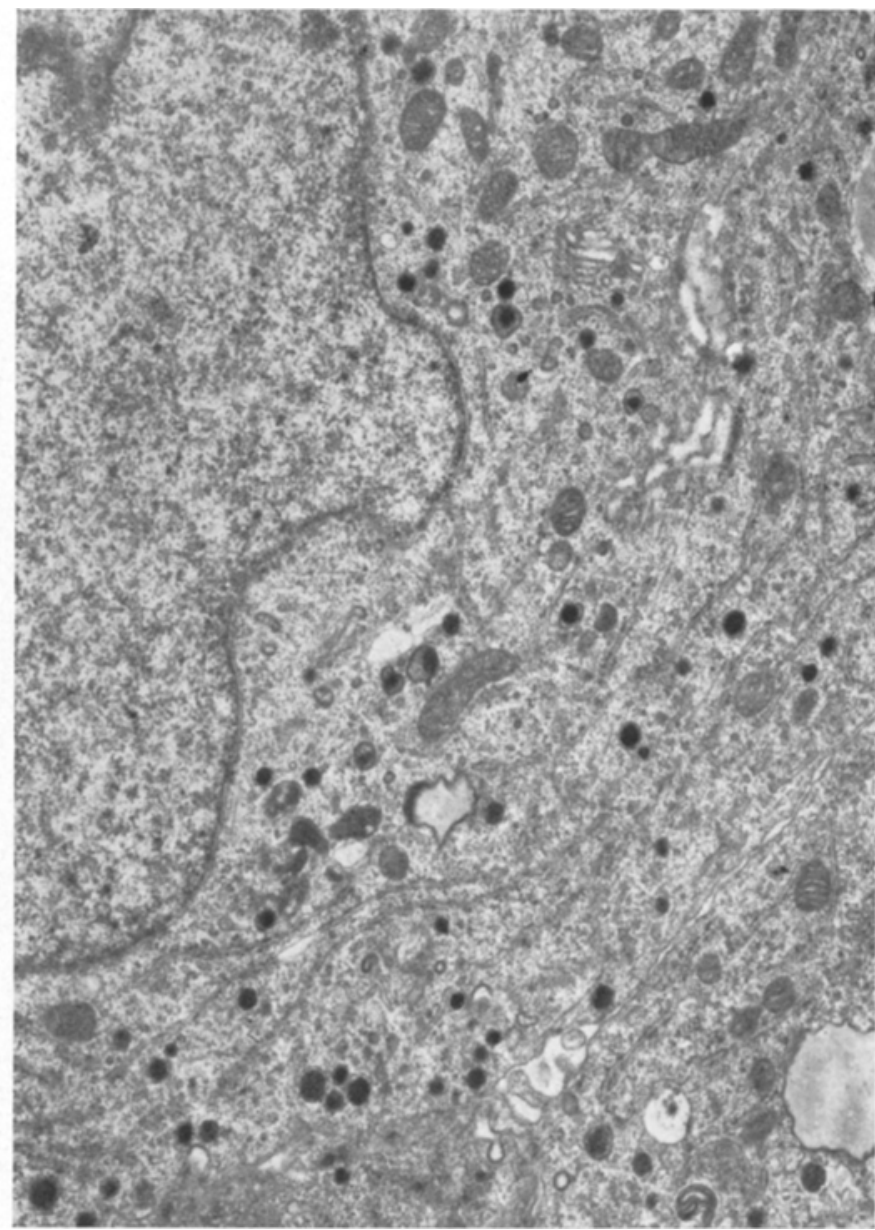

Fig. 6. Mouse Embryo 13 days. Shows part of an endocrine cell in the developing pancreas. The granules are mainly spherical, some resemble A granules but others are pleomorphic. A prominent Golgi region and many coated vesicles can be seen. Lead citrate-Uranyl acetate. $\times 12000$

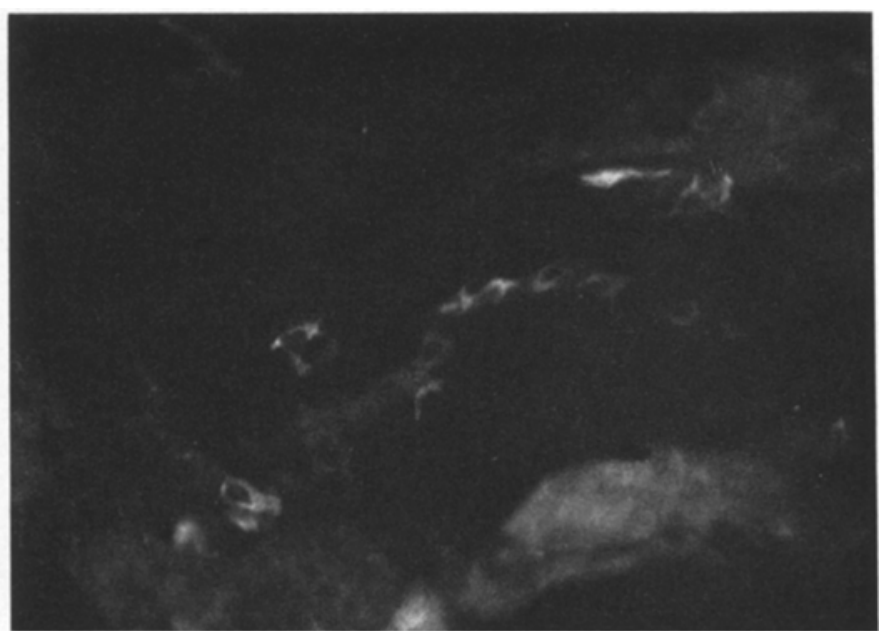

Fig. 8. As Fig. 7. Anti-porcine glucagon sera react with A cells in the definitive islets and also in the ducts. Single cells are found outside these situations. $\times 300$ 
the clear cells illustrated in Figs. 1 and 2, and for the dopamine-fluorescent cells in Fig. 3. Either they are arising from the gut epithelium and remaining in situ, or they are arising from the gut epithelium and going out, or they are arising outside the epithelium and coming in. We consider that there is sufficient evidence available to support the third deduction. If this is accepted then clearly there remain three more possibilities:

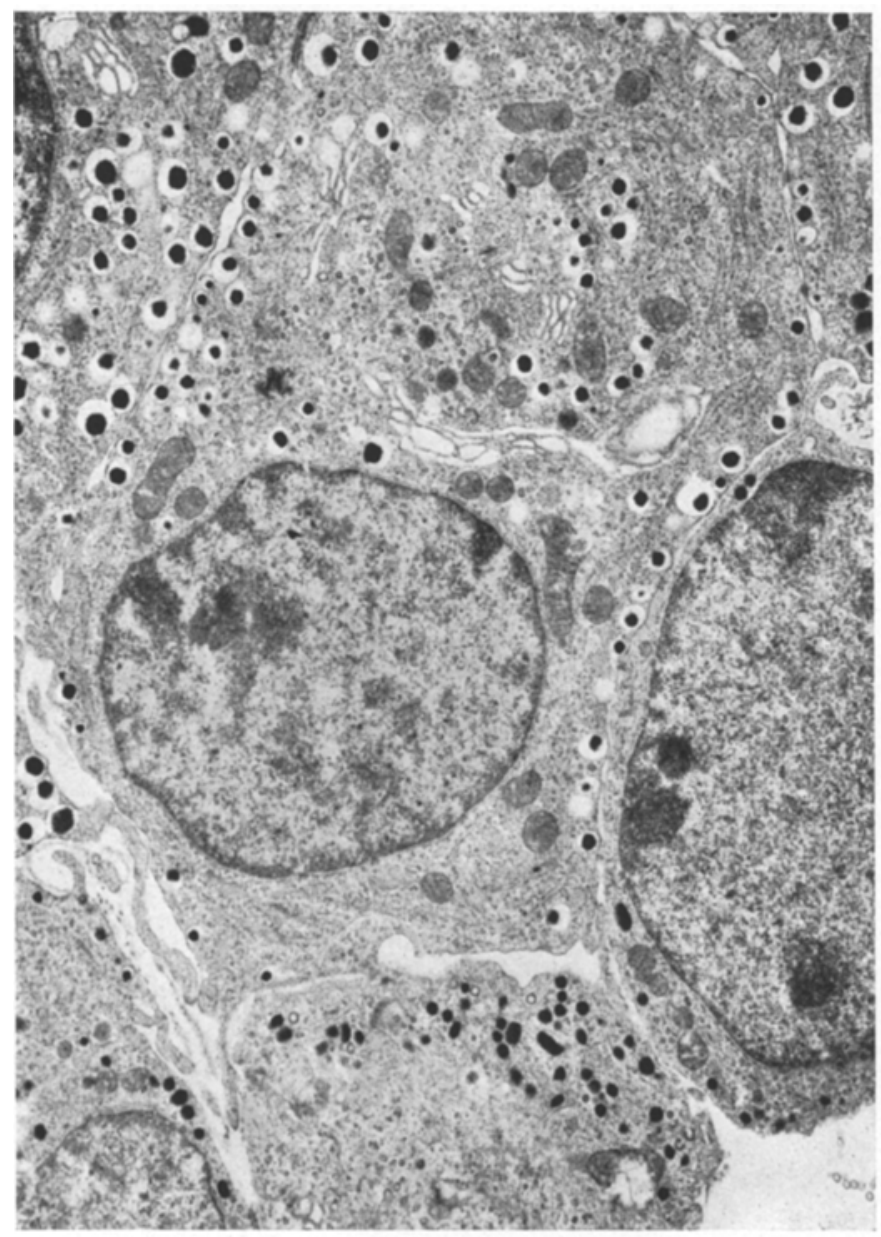

Fig. 9. Mouse Embryo 14 days. Pancreatic islet. Shows parts of five endocrine cells. One cell contains both round and pleomorphic granules. Two identifiable B cells, with prominent Golgi regions and coated vesicles are present and two cells with mixed granules identified as D cells. Lead citrate-Uranyl acetate. $\times 5000$

1. All the endocrine cells of the pancreatic islets are derived from duct epithelium or acinar cells.

2. All the endocrine cells of the pancreatic islets are derived from a neuroectodermal precursor which colonizes the gut wall and primordial pancreas at an early stage of development.

3 . Some of the endocrine cells are derived from the duct epithelium and others from the neural crest.

To accept the first of these suppositions as true it is necessary to assume that the colonizing neural crest cells die out, having perhaps first induced endocrine differentiation in the duct cells. The finding of dopamine labelled endocrine cell granules in the developing pancreas and of cells containing both the primitive pleomorphic granules characteristic of the neural crestderived APUD cells and spherical granules of specific endocrine type, is sufficient to make this supposition unlikely.

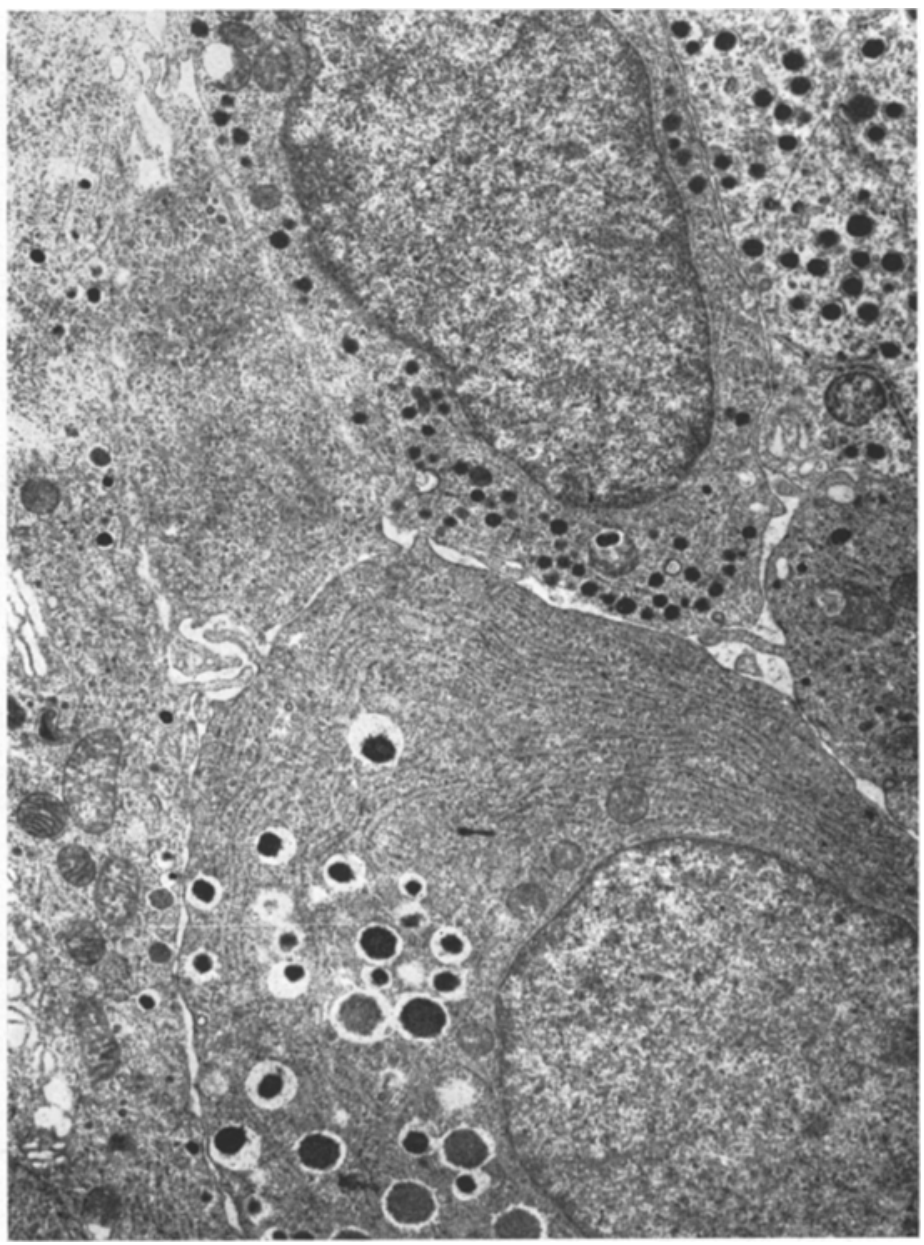

Fig. 10. Mouse Embryo 16 days. Pancreatic islet shows parts of several endocrine cells. An easily identifiable B cell now contains much rough endoplasmic reticulum and a single pleomorphic (biconcave) granule. A small portion of A cell cytoplasm contains the characteristic granules and a recognizable D cell is present. Lead citrate-Uranyl acetate. $\times 10000$

Our views on the second assumption are expressed in the diagram (Fig. 11) where the undifferentiated endocrine cells from the neural crest are shown (as clear cells) already in situ in the gut epithelium at the stage when the pancreatic anlagen are forming. Is there then sufficient evidence to warrant the assumption that all pancreatic endocrine cells are neuroectodermal, and thus lodgers in the duct epithelium. The answer at present is probably no, since the next 
step from the proven neural crest origin of the primitive endocrine cells has had to be made by ultrastructural criteria alone except for the cytochemical evidence of continuity between the APUD cell and at least one of the endocrine cells with round granules. We cannot yet dismiss, therefore, the third assumption, and the possible derivation of some endocrine cells from true duct epithelial (entodermal) cells.

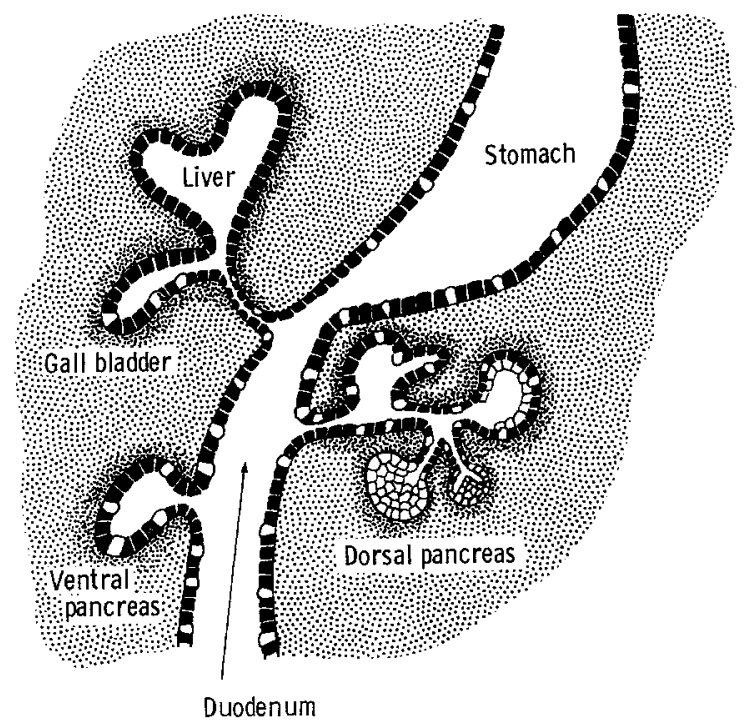

Fig. 11. Schematic representation of the distribution of endocrine (APUD) cells of neural crest origin in the primitive foregut ( 9 days) and its derivatives $(9-11$ days)

\section{References}

1. Laguesse, E.: Recherches sur l'histogenie du pancreas chez le Mouton. J. Anat. Physiol. 32, 209-350 (1869).

2. Hard, W.L.: The origin and differentiation of the alpha and beta cells in the pancreatic islets of the rat. Amer. J. Anat. 75, 369-403 (1944).

3. McAlpine, R.J.: Alkaline phosphatase in the developing endocrine pancreas of the albino rat. Anat. Rec. 109, $189-216(1951)$.

4. Ferreira, D.: L'ultrastructure des cellules du pancréas endocrine chez l'embryon et le rat nouveau-né. J. Ultrastructure Res. 1, 14-25 (1957).

5. Frye, B.E.: The differentiation of the endocrine pancreas in foetuses of Alloxan diabetes and insulin. treated rats. J. Morph. 101, 325-350 (1957).

6. Munger, B. L. : A light and electron microscopic study in cellular differentiation in the pancreatic islets of the mouse. Amer. J. Anat. 103, 275-312 (1958).

7. Esterhuizen, A.C.: The relationship between the alpha and beta cells in the islets of Langerhans of the albino rat. Sth. Afr. mod. J. 33, 197-201 (1959).

8. Golosow, N., Grobstein, C.: Epithelic-mesenchymal interaction in pancreatic morphogenesis. Develop. Biol. 4, 242-255 (1962)

9. Grillo, T.A.I.: The occurrence of insulin in pancreases of foetuses of some rodents. J. Endocr. 31, 67-73 (1964).

10. Hellman, B.: The development of the mammalian endocrine pancreas. Biol. Neonat. 9, 263-278 (1965/ $66)$.
11. Pictet, R., Clark, W.R., Renold, A.E., Williams, R., Rutter, W.J.: An electron microscopic study of the in vitro development of the embryonic rat pancreas. J. cell. Biol. 39, 105 a (Abstract) (1968).

12. Wessells, N.K., Rutter, W.J.: Phases in cell differentiation. Sei. Amer. 220, 36-44 (1969).

13. Perrier, H.: Evolution de l'ultrastructure du pancréas chez le foetus de rat. Diabetologia 6, 605-615 (1970).

14. Spooner, B.S., Walther, B.T., Rutter, W.J.: The development of the dorsal and ventral mammalian pancreas in vivo and in vitro. J. cell. Biol. 47, 235-246 (1970).

15. Pictet, R., Levine, S., Phelps, P., Rutter, W.J.: In vitro cytodifferentiation of rat embryonic pancreatic epithelium. Diabetes 20, Suppl. 1, 326 (1971).

16. Pearse, A.G.E.: The cytochemistry and ultrastructure of polypeptide hormone-producing cells of the APUD series, and the embryologic, physiologic and pathologic implications of the concept. J. Histochem. Cytochem. 17, 303-313 (1969).

17. Le Douarin, N., Le Lièvre, C.: Démonstration de l'origine neural des cellules à calcitonine du dorps ultimobranchial chez l'embryon de Poulet. C. R. Acad. Sci. Sér. D, 270, 2857-2860 (1970).

18. Pearse, A.G.E., Polak, Julia M.: Cytochemical evidence for the neural crest origin of mammalian ultimobranchial C cells. Histochemie 27, 96-102 (1971 a).

19. Le Douarin, N., Le Lièvre, C., Fontaine, J.: Recherches experimentales sur l'origine embryologique du corps caroditien chez les oiseaux. C. R. Acad. Sci. Sér. D. (1972 in press).

20. Pearse, A.G.E., Polak, Julia M.: Neural crest origin of the endocrine polypeptide cells of the gastrointestinal tract and pancreas. Gut 12, 783-788 1971b).

21. Lacy, P.E., Davies, J.: Demonstration of insulin in mammalian pancreas by the fluorescent antibody method. Stain Technol. 34, 85 (1959).

22. Baum, J., Simons, B.E., Unger, R. H., Madison, L. L. : Localization of glucagon in the alpha cells in the pancreatic islet by immunofluorescent technics. Diabetes 11, 371--374 (1962).

23. Lomsky, R., Langr, F., Vortel, V.: Site of glucagon in the islets of Langerhans of man as studied by the immunofluorescent technic. Sborn. ved. Praci léd. Fak. Hradci Kralové 11, 585-590 (1968).

24. Grüneberg, H.: The development of some external features in mouse embryo. J. Heredity 34, 89-92 (1943).

25. Polak, J.M., Bussolati, G., Pearse, A.G.E.: Cytochemical, immunofluorescence and ultrastructural investigations on the antral $G$ cells in hyperparathyroidism. Virchows Arch. Abt. B. Zellpath. 9, 187-197 (1971).

26. Pearse, A.G.E.: Histochemistry, Theoretical and Applied. Vol. 2, Ed. 3. London: Churchill-Livingstone 1972.

27. Grimelius, L.: A silver nitrate stain for $\alpha_{2}$ cells in human pancreatic islets. Acta Soc. Med. upsalien 73, $243-270$ (1968).

28. Gomori, G.: Microscopic histochemistry. University Press, Chicago (1952).

29. Hellerström, C., Hellman, B.: Some aspects of silver impregnation of the islets of Langerhans in the rat. Acta endocr. (Kbh.) 35, 518-532 (1960).

30. Coons, A.H., Leduc, E.H., Connolly, J.M. : Studies on anibody production. I. A method for the histochemical demonstration of specific antibody and its application to a study of the hyperimmune rabbit. J. exp. Med. 102, $49-60$ (1955).

31. Polak, J.M., Bloom, S., Coulling, I., Pearse, A.G.E.: Immunofluorescent localization of enteroglucagon cells in the gastrointestinal tract of the dog. Gut 12, $311-318$ (1971). 
32. Bensley, R.R.: Studies on the pancreas of the guinea pig. Amer. J. Anat. 12, $297-388$ (1911).

33. Liegner, B.: Studien zur Entwicklung des Pankreas, besonders der Langerhansschen. Inseln. Z. Zellforsch. 30, 494-529 (1932).

34. Rathery, F., Turiaf, J.: Influence de la castration et des injections de testosterone sur les îlots de Langerhans du pancréas du cobaye. C. R. Soc. Biol, 128, $155-156(1938)$.

35. Gomori, G.: Observations with differential stains on human islets of Langerhans. Amer. J. Path. 17, 395406 (1941).

36. Laguesse, M. E.: Ilots endocrines et formes de transition dans le lobule pancrétique (homme). C. r. Séanc. Soc. Biol. 58, 542-544 (1905).

37. Collin, R., Drouet, P.L., Watrin, J., Florentin, P.: Action histophysiologique de l'hypoglycémie sur la glande pituitaire la neurohypophyse et le tuber cinereum. C. R. Soc. Biol. 108,61-64 (1931).

38. Florentin, P., Picard, D., Weis, M. : Modifications du pancréas endocrine au cours de la gestation. C. R. Soc. Biol. 117, $188-189$ (1934).

39. Florentin, P., Picard, D.: Recherches sur le pancréas endocrine. Rev. franç. d'endocrinol. 14, 1-27 (1936).

40. Picard, D.: Sur un mode de formation de cellules langerhansiennes dans le pancréas. C. R. Soc. Biol. $120,153-154(1935)$.

41. Tusques, J.: La formation d'ilots de Langerhans aux dépens des acini dans le pancréas des castrats. C. R. Soc. Biol. 129, 1103-1106 (1938).

42. Woerner, C.A.: Studies of islands of Langerhans after continuous intravenous injection of dextrose. Anat. Rec. 71, 33-57 (1938).

43. Aubertin, E., Lacoste, A., Saric, R.: Action des injections répétées d'insuline sur l'état structural et fonctionnel du tissue langerhansien (étude expérimental et clinique). Ann. de méd. 43, 253-284 (1938).

44. Sergeyeva, M.A.: Microscopic changes in islands of Langerhans produced by sympathetic and parasympathetic stimulation in cat. Anat. Rec. 77, 297-317 (1940).

45. Simard, L.C.: Le complexe neuro-insulaire du pancréas chez les mammifères adultes. Rev. Canad. de Biol. 1, 2-49 (1942).

46. Stoeckenius, W., Kracht, J.: Elektronenmikroskopische Untersuchungen an den Langerhansschen Inseln der Ratte. Endokrinologie 36, 135-142 (1958).

47. Gusek, W., Kracht, J.: Elektronenmikroskopische Untersuchungen über Inselwachstum und acino-insuläre Transformation. Frankfurt Z. für Path. 70, $98-$ $106(1959)$.
48. Lange, R.: Uber die Variabilität und experimentelle Beeinflussung der Morphologie der Zelltypen im Inselapparat des Forsches Rana ridibunda. Z. Zellforsch. 88, 353-364 (1968).

49. Kobayashi, K.: Electron microscope studies of the Langerhans islets in the toad pancreas. Arch. histol. jap. 26, $439-482$ (1966).

50. Prieto-Diaz, H. E., Iturriza, F.C., Rodriguez, R.R. Acino-insular relationship in the pancreas of the toad investigated with the electron microscope. Acta anat. (Basel) 67, 291-303 (1967).

51. Dieterlen-Lièvre, F.: Étude morphologique et expérimentale de la différénciation du pancréas chez l'embryon de poulet. Bull. Biol. 99, 1 - 116 (1965).

52. Marx, M., Schmidt, W., Goberna, R.: Elektronenmikroskopische Untersuchungen zur Inselregeneration im. Rattenpankreas nach subtotaler pankreatektomie. Z. Zellforsch. 110, 569-587 (1970).

53. Marx, M., Schmidt, W., Hermann, M., Goberna, R.: Electron microscopic studies on the existence of the so called "acinar-islet cells" in the regenerating Pancreas of the rat. Horm. \& Metab. Res. 2, 204-212 (1970).

54. Brown, R.E., Still, W.J.S.: Acinar-islet cells in the exocrine pancreas of the adult cat. Amer. J. dig. Dis. $15,327-335(1970)$

55. Leduc, E.J., Jones, E. E. : Acinar-islet cell transformation in mouse pancreas. J. Ultrastructure Res. 24, $165-169(1968)$.

56. Melmed, R.N., Benitez, C.J., Holt, S. J.: Intermediate cells of the pancreas. I. Ultrastructural characterization. J. Cell Sci. 2, 449-475 (1972).

57. Orci, L., Lambert, A.E., Rouiller, Ch., Renold, A.E., Samols, E.: Evidence for the presence of A-cells in the endocrine fetal pancreas of the rat. Horm. \& Metab. Res. 1, 108-110 (1969).

58. Perrier, H., Porte, A., Jacquot, R.: Présence de cellules A dans le pancréas foetal de rat. C.R. Acad. Sci. 269, $841-843(1969)$.

59. Wessells, N.K., Evans, J.: Ultrastructural studies of early morphogenesis and cytodifferentiation in the embryonic mammalian pancreas. Dev. Biol. 17, 413446 (1968).

60. von Denffer, H., Mertz, M.: Empfindlichkeit einiger Farbstoffe zum Nachweis von $\beta$-Granula in den Inselzellen des Pankreas während der Ontogenese. Histochemie 29, 54-64 (1972).

Prof. A. G.E. Pearse

Dept. of Histochemistry

Royal Postgraduate Medical School

Hammersmith Hospital

London W. 12

England. 